\title{
Intake characteristics of perennial ryegrass varieties when grazed by yearling beef cattle under rotational grazing management
}

\author{
R. J. Orr, J. E. Cook, K. L. Young, R. A. Champion and S. M. Rutter \\ Institute of Grassland and Environmental Research, North Wyke, Okehampton, UK
}

\begin{abstract}
Four intermediate-heading perennial ryegrass (Lolium perenne L.) varieties, which in previous studies had been associated with high- or low-intake characteristics when swards containing them had been continuously stocked with sheep, were sown as monocultures. They were rotationally grazed, using 1 -d paddocks, with core groups of four yearling Simmental $\times$ Holstein beef heifers in 2002 and 2003 and ingestive and ruminative behaviour, and sward factors, were measured. There were two diploid (Belramo and Glen) and one tetraploid (Rosalin) perennial ryegrass varieties and one tetraploid hybrid (Lolium $\times$ boucheanum Kunth) (AberExcel) variety. Intake rate (IR) was significantly higher in August 2003 for heifers grazing Glen than those grazing Belramo $[27 \cdot 5$ vs. $20.6 \mathrm{~g}$ dry matter (DM) $\left.\min ^{-1} ; P=0.019\right]$, but there were no significant differences between varieties in two other measurement periods. This is in contrast to previous results with sheep when IR were significantly higher for Glen than Belramo and for AberExcel than Rosalin. Total jaw movement rates during grazing were significantly higher for heifers on the tetraploid swards than those on the diploid swards (87.7 vs. 83.6 jaw movements $\left.\min ^{-1} ; P=0.023\right)$ in September 2002. Ruminating time was significantly lower for heifers on the tetraploid swards than those on the diploid swards (453 vs. $519 \min 24 \mathrm{~h}^{-1} ; P=0.012$ ) in July 2002. Digestibility of grass snips was significantly higher on the tetraploid than the diploid swards [697 vs. $680 \mathrm{~g}$ digestible organic matter (DOM) $\mathrm{kg}^{-1} \mathrm{DM} ; P=0.042$ ] in September 2003 and, within diploids, was significantly higher for Glen than Belramo (696 vs. $\left.663 \mathrm{~g} \mathrm{DOM} \mathrm{kg}^{-1} \mathrm{DM} ; P=0 \cdot 014\right)$. There were significant differences in sheath tube and leaf lengths and in
\end{abstract}

Correspondence to: R. J. Orr, Institute of Grassland and Environmental Research, North Wyke, Okehampton, Devon EX20 2SB, UK.

E-mail: robert.orr@bbsrc.ac.uk

Received 11 November 2004; revised 18 February 2005 the population density of tillers between and within ploidies, which might have been expected to have influenced intake characteristics, but this was not generally found under rotational grazing with cattle. In order to separate the effects of defoliation interval from those of grazing style of the different ruminant species, it is suggested that grass variety evaluations using continuously stocked cattle swards are required.

Keywords: perennial ryegrass, varieties, intake rate, rotational grazing, cattle

\section{Introduction}

The assessment of intake characteristics of grass cultivars in grazing experiments (e.g. Barrett et al., 2003) is expensive in terms of land, animal and labour resources. However, the potential value of perennial ryegrass cultivars under grazing cannot necessarily be assessed from offering fresh or dried cut forage to housed animals (Hazard et al., 1998). Orr et al. (2003) measured large differences in dry matter (DM) intake rate (IR) between fifteen intermediate-heading perennial ryegrass (Lolium perenne L.) varieties when they were continuously stocked with sheep and subsequently explored the extent to which, for five of these varieties, these differences could be explained by chemical and morphological traits (Orr et al., 2004a). The objective of this study was to examine IR and eating times for four of the fifteen varieties, which within ploidy had low- or high-intake characteristics when grazed by sheep, to see if those attributes also held when swards containing these varieties were rotationally grazed by cattle. Sward chemical and morphological factors were also assessed.

\section{Materials and methods}

The experiment was conducted on a site at the Institute of Grassland and Environmental Research, North Wyke, Devon $\left(50^{\circ} 46^{\prime} \mathrm{N}, 3^{\circ} 56^{\prime} \mathrm{W}\right)$. Four intermediate-heading perennial ryegrass varieties [Belramo and Glen (diploid), Rosalin (tetraploid) and AberExcel (tetraploid hybrid, 
Lolium $\times$ boucheanum Kunth)] were compared when rotationally grazed by yearling Simmental $\times$ Holstein beef heifers. In previous studies, daily intakes by sheep had been 810, 904, 818 and 1104 g dry matter (DM) for Belramo, Glen, Rosalin and AberExcel respectively.

\section{Sward establishment}

The four varieties were each sown on 30 August 2000 in three replicate blocks to create twelve $(0 \cdot 6 \mathrm{ha})$ areas. Each area was further subdivided into thirty paddocks $(7 \cdot 4 \mathrm{~m} \times 27 \cdot 0 \mathrm{~m})$. A seed-sowing rate of $30 \mathrm{~kg} \mathrm{ha}^{-1}$ was used for the diploids and $40 \mathrm{~kg} \mathrm{ha}^{-1}$ for the tetraploid and tetraploid hybrid varieties. Fertilizer, which supplied $43 \mathrm{~kg} \mathrm{~N}, 60 \mathrm{~kg} \mathrm{P}_{2} \mathrm{O}_{5}$ and $60 \mathrm{~kg} \mathrm{~K}_{2} \mathrm{O} \mathrm{ha}{ }^{-1}$, was applied to the seed bed. In 2001, the whole experimental area was cut and the herbage removed on 3 June, 23 July and 18 September.

\section{Management}

The twelve treatment areas were each rotationally stocked using core groups of four heifers from 26 April to 25 October 2002 (born August 2001) and 24 April to 12 September 2003 (born August 2002). In 2003 only, there were an additional three heifers present in each group between 24 April and 26 June. This strategy was used in order to utilize some of the herbage growth in the early part of the season that was in excess of requirements for the cattle, but the group size was reduced in late June as the cattle grew larger. In 2002 and 2003, respectively, the core heifers (s.e.) had a live weight of $200(2.5) \mathrm{kg}$ and $190(3.6) \mathrm{kg}$ at the start of the grazing season and the same groups were maintained on the same treatments throughout each season. They grazed 1-d paddocks, had access to the previous day's paddock as a lie-back and moved to a new paddock at approximately 15:00 hours.

Uninterrupted spring growths were cut on two-thirds of each treatment area ( 0.4 ha) on 4 June 2002 and on one-third of each treatment area $(0 \cdot 2$ ha) on 20 May 2003. Following removal of the herbage, fertilizer, supplying $100 \mathrm{~kg} \mathrm{~N}$ and $64 \mathrm{~kg} \mathrm{~K}_{2} \mathrm{O} \mathrm{ha}{ }^{-1}$, was applied. Each year the grazed paddocks were fertilized with five applications of $40 \mathrm{~kg} \mathrm{~N} \mathrm{ha}^{-1}$ at approximately monthly intervals from March.

\section{Measurements}

\section{Intake rate}

Herbage IR was estimated throughout each year for the same two of the four heifers (chosen at random) grazing the four varieties in each replicate block on 10, 11 and 12 September 2002; on 14, 17 and 22 July 2003 and on
22, 26 and 27 August 2003 using a weighing technique (Penning and Hooper, 1985), modified for use on cattle (Huckle et al., 1994). Measurements were made when the heifers, which were trained to be accustomed to the procedure, were introduced to the new paddocks.

Heifers were weighed before and after a period of grazing of approximately $\mathrm{l} \mathrm{h}$, during which time the jaw movements were recorded using automatic behaviour recorders (Rutter et al., 1997). Recordings of jaw movement were subsequently analysed using 'Graze'TM software (Rutter, 2000) to calculate the duration of eating. Herbage samples were snipped from the grazed horizon using scissors and oven-dried at $80^{\circ} \mathrm{C}$ for $20 \mathrm{~h}$ for assessment of DM content. Herbage DM IR was calculated making an allowance for insensible weight loss, caused by evaporative and gaseous losses, determined in the preceding hour. Rate of insensible weight loss was measured by weighing heifers before and after a non-grazing period of approximately $\mathrm{l} \mathrm{h}$, when they were fitted with muzzles and allowed to walk within the paddock.

\section{Eating time and ruminating time}

Jaw movements were recorded over $24 \mathrm{~h}$ for the same two heifers that had been used for IR measurements, using the automatic behaviour recorders. Recordings were subsequently analysed to distinguish periods of eating, ruminating and idling and thus allow the calculation of eating time (Gibb, 1998). Measurements were made when the heifers moved to a new paddock at approximately 15:00 hours in each replicate block: in 2002 beginning on 1, 8 and 10 July and 29 August, 2 and 5 September, and in 2003 beginning on 6, 12 and 14 May; 15, 23 and 30 July and 28 August, 4 and 8 September. Snip samples were cut from the grazed horizon using scissors before the heifers entered the paddocks for these 24-h behaviour measurements and were rapidly frozen, freeze-dried and analysed for DM content as described below.

Data for eating time and ruminating time included pauses of $<3 \mathrm{~s}$ between successive jaw movements (i.e. the minimum inter-bout interval was $3 \mathrm{~s}$ ), and an eating bout and a ruminating bout each contained at least 10 jaw movements. Jaw movements that did not satisfy these criteria were broadly designated as 'other activities', e.g. drinking, grooming, vocalization, etc. Individual rumination bouts associated with the eructation of each bolus were combined using a minimum inter-rumination bout interval of $20 \mathrm{~s}$.

\section{Sward height, mass and sheath tubelleaf lengths}

Compressed sward height ( $\mathrm{CSH})$ was measured when IR and grazing behaviour measurements were made 
using an Ashgrove platemeter (Ashgrove Pastoral Products, Palmerston North, New Zealand) with 25 contacts per paddock. The partition of herbage mass between live and dead material, and the tiller population density (tillers $\mathrm{m}^{-2}$ ), were measured within circular quadrats with the same diameter $(354 \mathrm{~mm})$ as the platemeter when grazing-behaviour measurements were made. The grass was cut to ground level (Frame, 1981; Thomson et al., 1997) using scissors and subsamples of 50-60 grass tillers were separated into green leaves, green vegetative and reproductive stems, and dead material. Reproductive tillers in the subsample were identified on the basis of internode elongation and the numbers of both reproductive and vegetative tillers in the subsample were counted. The dry weight (ovendrying at $85^{\circ} \mathrm{C}$ for $18 \mathrm{~h}$ ) of the components and the number of tillers were calculated from the contribution of their weight to the total weight of the respective subsamples and the total sample weight.

Sheath tube and leaf lengths (Casey, 2000) were measured after the removal of senescent material on the tillers in the subsample, with lamina containing proportionately $>0.50$ of dead surface tissue being classified as dead. Sheath tube lengths were measured from the root/shoot interface.

\section{Chemical analyses}

Freeze-dried grass snips from the grazed horizon, collected in association with the 24 -h behaviour measurements, were analysed for digestible organic matter in the DM (DOMD in vitro; Jones and Haywood, 1975), for nitrogen $(\mathrm{N})$ concentration by the Kjeldahl method, with copper sulphate as a catalyst, using a Tecator 1030 auto analyser (Tecator, 1987), and for water-soluble carbohydrate (WSC) concentration (Thomas, 1977).

\section{Statistical analysis}

The results were analysed as a one-way randomized block design $(n=12)$ using GenStat (GENSTAT, 1987). The effects of ploidy and variety within ploidy were examined by using orthogonal contrasts. Mean values for the two measured heifers in each of the twelve groups were used as the unit of replication, as were mean values per paddock when analysing the herbage data.

\section{Results}

Compressed sward heights when IR was measured in September 2002, and July and August 2003, respectively, were $11 \cdot 2,10 \cdot 7$ and $9.3 \mathrm{~cm}$ and there were no significant differences in sward height between treatment paddocks.

\section{IR and jaw movement rates}

Apart from the within-diploid comparison between Glen and Belramo $(P=0 \cdot 019)$, there were no significant differences in grass DM IR (Table 1). Grass DM IR tended to be higher on the tetraploid varieties than the diploids in September 2002 and July 2003, whereas the IR was markedly higher on Glen (diploid) in August 2003 than the other varieties.

In September 2002, jaw movement rate was significantly higher for cattle grazing the tetraploids than those grazing the diploids $(P=0 \cdot 023)$. There were no significant differences between treatments in biting, chewing or total jaw movement rates in 2003. There were no significant differences between treatments in DM content of the grass snips and mean values were 224, 224 and $236 \mathrm{~g} \mathrm{~kg}^{-1}$ in September 2002, July 2003 and August 2003 respectively.

\section{Eating and ruminating}

There were no significant differences between varieties in daily time spent eating (Table 2). Overall mean values for diploid and tetraploid varieties were 529 and 531 min eating $24 \mathrm{~h}^{-1}$ respectively.

Daily time spent ruminating (Table 2) was significantly lower for heifers grazing the tetraploid varieties than the diploids in July $2002(P=0 \cdot 012)$, but otherwise ruminating time was similar between treatments. Overall mean values for diploid and tetraploid varieties were 467 and $442 \mathrm{~min}$ ruminating $24 \mathrm{~h}^{-1}$ respectively. There were no significant effects of variety on the rumination chewing rate or the number of chews per bolus.

\section{Digestibility, nitrogen and WSC concentrations in grass snips}

Digestibility of the grass snips taken before the heifers entered a new paddock (Table 3) was significantly higher for the diploid varieties than the tetraploids in September $2003(P=0.042)$ and, within the diploids, Glen was significantly higher than Belramo $(P=$ $0 \cdot 014)$. Overall mean values for Belramo, Glen, Rosalin and AberExcel, respectively, were 703, 719, 709 and $719 \mathrm{~g} \mathrm{DOM} \mathrm{kg}^{-1} \mathrm{DM}$.

Nitrogen concentrations in the grass snips were significantly higher for AberExcel than Rosalin in September $2002(P=0.013)$ and tended to be higher for tetraploid than diploid varieties in September 2003. Values tended to increase as the season progressed. In 2003, however, values were higher in May than July or September. Overall mean values for Belramo, Glen, Rosalin and AberExcel were 3.2, 3.1, $3 \cdot 2$ and $3.4 \mathrm{~g} \mathrm{~N} \mathrm{~kg}^{-1}$ DM respectively. 
Table I Intake rate, grazing jaw movement rates and grass dry matter (DM) content for the first hour following introduction of the Simmental $\times$ Holstein heifers to a new paddock at approximately 15:00 hours in 2002 and 2003.

\begin{tabular}{|c|c|c|c|c|c|c|c|c|}
\hline & \multicolumn{4}{|c|}{ Variety } & \multicolumn{4}{|c|}{ Level of significance } \\
\hline & Belramo (d) & Glen (d) & Rosalin (t) & AberExcel (th) & s.e.d. & Ploidy & $\begin{array}{l}\text { Belramo vs. } \\
\text { Glen }\end{array}$ & $\begin{array}{l}\text { Rosalin vs. } \\
\text { AberExcel }\end{array}$ \\
\hline \multicolumn{9}{|c|}{ Intake rate $\left(\mathrm{g} \mathrm{DM} \mathrm{min}^{-1}\right)$} \\
\hline September 2002 & $31 \cdot 5$ & $32 \cdot 2$ & $34 \cdot 5$ & $34 \cdot 4$ & $5 \cdot 20$ & $0 \cdot 507$ & $0 \cdot 897$ & $0 \cdot 984$ \\
\hline July 2003 & $19 \cdot 4$ & $21 \cdot 2$ & $22 \cdot 7$ & $22 \cdot 3$ & 1.99 & $0 \cdot 171$ & $0 \cdot 388$ & 0.823 \\
\hline August 2003 & $20 \cdot 6$ & $27 \cdot 5$ & $22 \cdot 8$ & $24 \cdot 0$ & $2 \cdot 16$ & $0 \cdot 699$ & $0 \cdot 019$ & $0 \cdot 617$ \\
\hline \multicolumn{9}{|l|}{ Biting rate $\left(\min ^{-1}\right)$} \\
\hline September 2002 & $65 \cdot 4$ & $65 \cdot 3$ & $68 \cdot 9$ & $69 \cdot 0$ & $2 \cdot 64$ & $0 \cdot 100$ & 0.975 & 0.990 \\
\hline July 2003 & $69 \cdot 9$ & $65 \cdot 8$ & $61 \cdot 4$ & $65 \cdot 4$ & $3 \cdot 58$ & $0 \cdot 129$ & $0 \cdot 296$ & $0 \cdot 300$ \\
\hline August 2003 & $67 \cdot 1$ & $66 \cdot 9$ & $67 \cdot 1$ & $65 \cdot 6$ & $2 \cdot 06$ & $0 \cdot 705$ & 0.932 & 0.493 \\
\hline \multicolumn{9}{|l|}{ Chewing rate $\left(\mathrm{min}^{-1}\right)$} \\
\hline September 2002 & $17 \cdot 1$ & $19 \cdot 4$ & $17 \cdot 8$ & $19 \cdot 7$ & $1 \cdot 96$ & $0 \cdot 722$ & $0 \cdot 280$ & $0 \cdot 382$ \\
\hline July 2003 & $17 \cdot 9$ & $20 \cdot 6$ & $25 \cdot 9$ & $23 \cdot 2$ & $3 \cdot 63$ & $0 \cdot 084$ & $0 \cdot 483$ & $0 \cdot 490$ \\
\hline August 2003 & $20 \cdot 1$ & $18 \cdot 3$ & $19 \cdot 9$ & $20 \cdot 0$ & $2 \cdot 84$ & 0.715 & 0.545 & 0.955 \\
\hline \multicolumn{9}{|l|}{ TJM rate $\left(\min ^{-1}\right)$} \\
\hline September 2002 & $82 \cdot 4$ & $84 \cdot 7$ & $86 \cdot 8$ & $88 \cdot 6$ & 1.93 & 0.023 & $0 \cdot 289$ & $0 \cdot 366$ \\
\hline July 2003 & $87 \cdot 8$ & $86 \cdot 4$ & $87 \cdot 2$ & $88 \cdot 6$ & $1 \cdot 50$ & $0 \cdot 448$ & $0 \cdot 393$ & $0 \cdot 389$ \\
\hline August 2003 & $87 \cdot 2$ & $85 \cdot 1$ & $87 \cdot 0$ & $85 \cdot 7$ & 1.96 & $0 \cdot 894$ & $0 \cdot 344$ & $0 \cdot 520$ \\
\hline \multicolumn{9}{|c|}{ Grass DM content $\left(\mathrm{g} \mathrm{kg}^{-1}\right)$} \\
\hline September 2002 & 225 & 217 & 230 & 225 & $17 \cdot 7$ & 0.630 & $0 \cdot 672$ & $0 \cdot 811$ \\
\hline July 2003 & 226 & 213 & 229 & 229 & $16 \cdot 9$ & $0 \cdot 461$ & $0 \cdot 490$ & 0.995 \\
\hline August 2003 & 239 & 244 & 232 & 229 & $13 \cdot 3$ & $0 \cdot 301$ & $0 \cdot 758$ & $0 \cdot 839$ \\
\hline
\end{tabular}

(d) diploid; (t) tetraploid; (th) tetraploid hybrid.

TJM, total jaw movements (biting + chewing).

Water-soluble carbohydrate concentrations in the grass snips were not significantly different between the varieties and, unlike the $\mathrm{N}$ concentrations, tended to decrease as the season progressed. Overall mean values for Belramo, Glen, Rosalin and AberExcel were $17 \cdot 5,18 \cdot 6,17 \cdot 8$ and $17 \cdot 9 \mathrm{~g}$ WSC $\mathrm{kg}^{-1}$ DM respectively.

\section{Daily liveweight gain}

The liveweight gains of the heifers during the grazing season were high in both years and mean values were 0.98 and $1.02 \mathrm{~kg} \mathrm{day}^{-1}$ for 2002 and 2003 respectively. However, there were no significant differences in daily liveweight gain between the treatments (Table 4) in either year.

\section{Compressed sward height, green leaf mass and the number of tillers per square metre}

Compressed sward height (Table 5) at the start (IN) and end (OUT) of 24-h grazing periods, when behaviour was recorded, was significantly higher in AberExcel than Rosalin in July $2002(P=0 \cdot 025)$. Overall mean values for Belramo, Glen, Rosalin and AberExcel were
$10 \cdot 9,11 \cdot 9,11 \cdot 5$ and $12 \cdot 8 \mathrm{~cm}(\mathrm{IN})$ and $6 \cdot 6,7 \cdot 0,6.9$ and $7 \cdot 0 \mathrm{~cm}$ (OUT) respectively.

Green leaf mass (Table 6) was not significantly different between the varieties and declined with season. For example, overall mean values across the four varieties in May, July and September 2003 were 2027, 1239 and $1034 \mathrm{~kg} \mathrm{DM} \mathrm{ha}^{-1}$ respectively.

There were significant effects of ploidy on the tiller population density per square metre (Table 6) in July $2002(P=0 \cdot 004)$, May $2003(P=0.002)$ and July 2003 $(P=0.004)$ with higher values for the diploid than the tetraploid varieties. Within ploidies, Rosalin was higher than AberExcel in July $2002(P=0.025)$ and Glen was higher than Belramo in May $2003(P=0 \cdot 019)$. Overall mean values for Belramo, Glen, Rosalin and AberExcel were $10008,10998,8356$ and 6112 tillers $\mathrm{m}^{-2}$ respectively.

\section{Sheath tube and leaf lengths}

There were significant effects of ploidy on sheath tube and leaf lengths associated with live leaves (Table 7) in July each year. For diploid vs. tetraploid varieties, overall mean values for the sheath tubes were 38 vs. 
Table 2 Eating time, ruminating time, ruminating chewing rate and the number of chews per bolus in 2002 and 2003.

\begin{tabular}{|c|c|c|c|c|c|c|c|c|}
\hline & \multicolumn{4}{|c|}{ Variety } & \multirow[b]{2}{*}{ s.e.d. } & \multicolumn{3}{|c|}{ Level of significance } \\
\hline & Belramo (d) & Glen (d) & Rosalin (t) & AberExcel (th) & & Ploidy & $\begin{array}{l}\text { Belramo vs. } \\
\text { Glen }\end{array}$ & $\begin{array}{l}\text { Rosalin vs. } \\
\text { AberExcel }\end{array}$ \\
\hline \multicolumn{9}{|c|}{ Eating time $\left(\min 24 \mathrm{~h}^{-1}\right)$} \\
\hline July 2002 & 571 & 550 & 567 & 614 & $38 \cdot 7$ & $0 \cdot 319$ & 0.597 & $0 \cdot 264$ \\
\hline September 2002 & 521 & 511 & 515 & 542 & $35 \cdot 0$ & $0 \cdot 630$ & $0 \cdot 791$ & $0 \cdot 477$ \\
\hline May 2003 & 492 & 485 & 491 & 508 & $28 \cdot 2$ & $0 \cdot 621$ & 0.815 & 0.569 \\
\hline July 2003 & 561 & 567 & 496 & 551 & $42 \cdot 2$ & $0 \cdot 224$ & $0 \cdot 891$ & $0 \cdot 238$ \\
\hline September 2003 & 496 & 536 & 528 & 501 & $26 \cdot 5$ & $0 \cdot 932$ & $0 \cdot 183$ & $0 \cdot 348$ \\
\hline \multicolumn{9}{|c|}{ Ruminating time $\left(\min 24 \mathrm{~h}^{-1}\right.$ ) } \\
\hline July 2002 & 522 & 516 & 432 & 474 & $26 \cdot 3$ & $0 \cdot 012$ & $0 \cdot 836$ & $0 \cdot 160$ \\
\hline September 2002 & 477 & 441 & 411 & 452 & $42 \cdot 3$ & $0 \cdot 387$ & $0 \cdot 429$ & $0 \cdot 368$ \\
\hline May 2003 & 457 & 485 & 414 & 448 & $51 \cdot 3$ & $0 \cdot 313$ & $0 \cdot 609$ & 0.536 \\
\hline July 2003 & 431 & 407 & 399 & 446 & $38 \cdot 1$ & $0 \cdot 892$ & $0 \cdot 558$ & $0 \cdot 262$ \\
\hline September 2003 & 463 & 473 & 465 & 482 & $13 \cdot 5$ & $0 \cdot 558$ & $0 \cdot 489$ & $0 \cdot 254$ \\
\hline \multicolumn{9}{|c|}{ Ruminating chews $\min ^{-1}$} \\
\hline July 2002 & $77 \cdot 9$ & $79 \cdot 8$ & $77 \cdot 6$ & $78 \cdot 3$ & $2 \cdot 55$ & $0 \cdot 635$ & $0 \cdot 479$ & $0 \cdot 817$ \\
\hline September 2002 & $73 \cdot 6$ & $75 \cdot 3$ & $71 \cdot 2$ & $71 \cdot 0$ & $2 \cdot 32$ & $0 \cdot 086$ & $0 \cdot 489$ & $0 \cdot 943$ \\
\hline May 2003 & $83 \cdot 0$ & $84 \cdot 4$ & $80 \cdot 6$ & $83 \cdot 1$ & $4 \cdot 15$ & 0.552 & 0.756 & 0.565 \\
\hline July 2003 & $72 \cdot 9$ & $74 \cdot 0$ & $73 \cdot 5$ & $75 \cdot 1$ & $4 \cdot 47$ & $0 \cdot 803$ & $0 \cdot 813$ & $0 \cdot 730$ \\
\hline September 2003 & $73 \cdot 9$ & $75 \cdot 6$ & $75 \cdot 3$ & $76 \cdot 0$ & $3 \cdot 88$ & $0 \cdot 758$ & 0.671 & 0.857 \\
\hline \multicolumn{9}{|c|}{ Ruminating chews bolus $^{-1}$} \\
\hline July 2002 & $58 \cdot 1$ & $54 \cdot 9$ & $59 \cdot 9$ & $58 \cdot 3$ & $4 \cdot 57$ & $0 \cdot 450$ & $0 \cdot 512$ & $0 \cdot 737$ \\
\hline September 2002 & $58 \cdot 6$ & $57 \cdot 9$ & $56 \cdot 8$ & $63 \cdot 6$ & $5 \cdot 19$ & $0 \cdot 608$ & 0.891 & $0 \cdot 240$ \\
\hline May 2003 & $68 \cdot 1$ & $67 \cdot 3$ & $60 \cdot 9$ & $66 \cdot 6$ & $5 \cdot 30$ & $0 \cdot 328$ & 0.878 & 0.325 \\
\hline July 2003 & $63 \cdot 2$ & $59 \cdot 5$ & $56 \cdot 8$ & $59 \cdot 8$ & $4 \cdot 06$ & 0.333 & $0 \cdot 391$ & $0 \cdot 494$ \\
\hline September 2003 & $67 \cdot 4$ & $68 \cdot 3$ & $65 \cdot 0$ & $65 \cdot 2$ & $4 \cdot 38$ & $0 \cdot 409$ & $0 \cdot 848$ & 0.969 \\
\hline
\end{tabular}

(d) diploid; (t) tetraploid; (th) tetraploid hybrid.

$44 \mathrm{~mm}$ (oldest), 56 vs. $70 \mathrm{~mm}$ (second oldest) and for leaf lengths were 89 vs. $100 \mathrm{~mm}$ (oldest fully expanded), 114 vs. $138 \mathrm{~mm}$ (second oldest fully expanded) and 73 vs. $85 \mathrm{~mm}$ (expanding leaf). There were significant differences within ploidies in July 2002. On average, over the five measurement periods, values for Glen were generally greater than those for Belramo and values for AberExcel were generally greater than those for Rosalin for each of these factors but this was not always the case (Table 7). In 2003, values were higher in May than in July or September.

\section{Discussion}

Previous studies have compared the performance of perennial ryegrass varieties under grazing, but generally have not measured intake (e.g. Swift et al., 1993; McCallum and Thomson, 1994; Emile et al., 2000). However, Gowen et al. (2003) examined heading date and ploidy effects for four cultivars on grass intake and milk yield for rotationally grazed dairy cows. They concluded that late-heading grass cultivars have a beneficial effect on milk yield, but used the individual cows as the unit of replication in their analyses. This approach was questioned by Rook and Penning (1991) who argued that the behaviour and performance of individuals cannot be regarded as being independent. In this study, IR was measured for four contrasting perennial ryegrass varieties, with three replicate groups of each, along with sward chemical and morphological traits which could potentially be used to identify lines with superior grazing characteristics.

\section{IR in cattle and sheep}

Apart from August 2003, when IR was significantly higher for cattle grazing Glen than for those grazing Belramo, there were no significant differences in IR within or between ploidies. Similarly, there were no significant differences between varieties in biting rate (mean 66.5 bites $\min ^{-1}$ ), chewing rate while grazing (mean $20 \cdot 0$ chews $\mathrm{min}^{-1}$ ), eating times (mean $530 \mathrm{~min}$ $24 \mathrm{~h}^{-1}$ ), ruminating times (mean $455 \min 24 \mathrm{~h}^{-1}$ ) and 
Table 3 Digestibility (digestible organic matter in the dry matter DOMD), nitrogen (N) and water-soluble carbohydrate (WSC) concentrations in grass snip samples taken before the heifers received their daily allocation of grass in 2002 and 2003.

\begin{tabular}{|c|c|c|c|c|c|c|c|c|}
\hline & \multicolumn{4}{|c|}{ Variety } & \multirow[b]{2}{*}{ s.e.d. } & \multicolumn{3}{|c|}{ Level of significance } \\
\hline & Belramo (d) & Glen (d) & Rosalin (t) & AberExcel (th) & & Ploidy & $\begin{array}{l}\text { Belramo vs. } \\
\text { Glen }\end{array}$ & $\begin{array}{l}\text { Rosalin vs. } \\
\text { AberExcel }\end{array}$ \\
\hline \multicolumn{9}{|c|}{ DOMD (g DOM kg $\left.{ }^{-1} \mathrm{DM}\right)$} \\
\hline July 2002 & 714 & 717 & 728 & 722 & $12 \cdot 9$ & $0 \cdot 341$ & $0 \cdot 824$ & 0.666 \\
\hline September 2002 & 731 & 715 & 703 & 733 & $14 \cdot 7$ & $0 \cdot 642$ & $0 \cdot 340$ & $0 \cdot 088$ \\
\hline May 2003 & 720 & 737 & 733 & 763 & $15 \cdot 9$ & $0 \cdot 128$ & $0 \cdot 329$ & $0 \cdot 110$ \\
\hline July 2003 & 689 & 730 & 687 & 678 & $22 \cdot 9$ & $0 \cdot 156$ & $0 \cdot 123$ & $0 \cdot 706$ \\
\hline September 2003 & 663 & 696 & 696 & 698 & $9 \cdot 6$ & $0 \cdot 042$ & $0 \cdot 014$ & $0 \cdot 846$ \\
\hline \multicolumn{9}{|l|}{$\mathrm{N}\left(\mathrm{g} \mathrm{kg}^{-1} \mathrm{DM}\right)$} \\
\hline July 2002 & 31 & 25 & 28 & 29 & $3 \cdot 0$ & $0 \cdot 866$ & $0 \cdot 102$ & $0 \cdot 693$ \\
\hline September 2002 & 38 & 38 & 33 & 45 & $3 \cdot 3$ & $0 \cdot 740$ & 0.995 & 0.013 \\
\hline May 2003 & 24 & 21 & 28 & 27 & $5 \cdot 7$ & $0 \cdot 266$ & 0.598 & $0 \cdot 833$ \\
\hline July 2003 & 31 & 34 & 29 & 31 & $3 \cdot 3$ & $0 \cdot 266$ & $0 \cdot 384$ & $0 \cdot 618$ \\
\hline September 2003 & 36 & 38 & 40 & 39 & $1 \cdot 7$ & 0.071 & $0 \cdot 274$ & $0 \cdot 401$ \\
\hline \multicolumn{9}{|l|}{ WSC ( $\left.\mathrm{g} \mathrm{kg}^{-1} \mathrm{DM}\right)$} \\
\hline July 2002 & 193 & 220 & 206 & 189 & $22 \cdot 8$ & 0.622 & $0 \cdot 284$ & $0 \cdot 484$ \\
\hline September 2002 & 131 & 134 & 129 & 112 & $8 \cdot 6$ & 0.098 & 0.799 & $0 \cdot 097$ \\
\hline May 2003 & 270 & 289 & 266 & 303 & 31.9 & 0.850 & 0.576 & $0 \cdot 294$ \\
\hline July 2003 & 151 & 149 & 162 & 152 & 11.9 & $0 \cdot 460$ & $0 \cdot 858$ & $0 \cdot 451$ \\
\hline September 2003 & 131 & 139 & 129 & 140 & $9 \cdot 2$ & $0 \cdot 956$ & $0 \cdot 389$ & $0 \cdot 286$ \\
\hline
\end{tabular}

(d) diploid; (t) tetraploid; (th) tetraploid hybrid.

Table 4 Daily liveweight gain $\left(\mathrm{kg} \mathrm{day}^{-1}\right)$ from turnout to the end of the grazing season in 2002 and 2003.

\begin{tabular}{|c|c|c|c|c|c|c|c|c|}
\hline & \multicolumn{4}{|c|}{ Variety } & \multirow[b]{2}{*}{ s.e.d } & \multicolumn{3}{|c|}{ Level of significance } \\
\hline & Belramo (d) & Glen (d) & Rosalin (t) & AberExcel (th) & & Ploidy & $\begin{array}{l}\text { Belramo vs. } \\
\text { Glen }\end{array}$ & $\begin{array}{l}\text { Rosalin vs. } \\
\text { AberExcel }\end{array}$ \\
\hline \multicolumn{9}{|c|}{ Daily liveweight gain $\left(\mathrm{kg} \mathrm{day}^{-1}\right)$} \\
\hline 2002 & $1 \cdot 00$ & 1.02 & 0.99 & 0.92 & $0 \cdot 12$ & $0 \cdot 151$ & 0.663 & $0 \cdot 220$ \\
\hline 2003 & 0.96 & $1 \cdot 13$ & $1 \cdot 02$ & 0.96 & 0.08 & 0.416 & 0.091 & 0.469 \\
\hline
\end{tabular}

(d) diploid; (t) tetraploid; (th) tetraploid hybrid.

ruminating chews (mean $76.6 \mathrm{~min}^{-1}$ and 61.8 bolus $^{-1}$ ). These measurements were undertaken over a relatively long time-scale, with three replicate areas of each variety. It can be concluded, therefore, that the lack of difference in intake characteristics is real, it can be viewed with some confidence and is supported by the animal performance data.

When the same four varieties that were used in the present experiment were grazed continuously by sheep in 1998 and 1999 (Orr et al., 2003), average IR for the 2 years was markedly higher for Glen than Belramo (1555 vs. $1160 \mathrm{mg} \mathrm{DM} \mathrm{min}{ }^{-1}$ ) and for AberExcel than Rosalin ( 1778 vs. $1218 \mathrm{mg} \mathrm{DM} \mathrm{min}^{-1}$ ). In a subsequent experiment, conducted in 2000, which included three of the varieties (Orr et al., 2004a) IR for similar continuously stocked sheep were 1165, 1089 and 1390 (mg DM $\mathrm{min}^{-1}$ ) for Glen, Belramo and AberExcel, respectively, i.e. the rankings were similar to the previous sheep data, although these differences were not significant in the latter experiment. However, both animal species (cattle vs. sheep) and grazing management (rotational vs. continuous stocking) changed between this and the previous studies. Therefore, there is a need to identify more closely the mechanisms involved and grass variety evaluations using continuously stocked cattle swards are required in order to separate the effects of defoliation interval from those of grazing style of the different animal species. Nevens and Reheul (2003), in a long-term study, suggested that potential differences between grass varieties were 
Table 5 Compressed sward height at the start (IN) and end (OUT) of grazing periods in which grazing and ruminating behaviour was measured over $24 \mathrm{~h}$ in 2002 and 2003.

\begin{tabular}{|c|c|c|c|c|c|c|c|c|}
\hline & \multicolumn{4}{|c|}{ Variety } & \multirow[b]{2}{*}{ s.e.d } & \multicolumn{3}{|c|}{ Level of significance } \\
\hline & Belramo (d) & Glen (d) & Rosalin (t) & AberExcel (th) & & Ploidy & $\begin{array}{l}\text { Belramo vs. } \\
\text { Glen }\end{array}$ & $\begin{array}{l}\text { Rosalin vs. } \\
\text { AberExcel }\end{array}$ \\
\hline \multicolumn{9}{|c|}{ Compressed sward height $(\mathrm{cm})$} \\
\hline \multicolumn{9}{|l|}{ IN } \\
\hline July 2002 & $10 \cdot 8$ & $13 \cdot 0$ & $11 \cdot 9$ & $16 \cdot 1$ & $1 \cdot 32$ & 0.075 & $0 \cdot 147$ & 0.025 \\
\hline September 2002 & $10 \cdot 2$ & $11 \cdot 5$ & $11 \cdot 1$ & $9 \cdot 7$ & 0.69 & 0.438 & $0 \cdot 120$ & $0 \cdot 103$ \\
\hline May 2003 & $15 \cdot 9$ & $15 \cdot 2$ & $15 \cdot 7$ & $18 \cdot 4$ & $3 \cdot 62$ & 0.591 & $0 \cdot 871$ & $0 \cdot 512$ \\
\hline July 2003 & $9 \cdot 1$ & $10 \cdot 5$ & $10 \cdot 3$ & $10 \cdot 8$ & $1 \cdot 12$ & $0 \cdot 396$ & $0 \cdot 248$ & $0 \cdot 699$ \\
\hline September 2003 & $8 \cdot 7$ & $9 \cdot 5$ & $8 \cdot 4$ & $9 \cdot 2$ & $0 \cdot 68$ & 0.583 & 0.301 & $0 \cdot 265$ \\
\hline \multicolumn{9}{|l|}{ OUT } \\
\hline July 2002 & $6 \cdot 6$ & $8 \cdot 0$ & $7 \cdot 7$ & $8 \cdot 8$ & $0 \cdot 48$ & 0.032 & $0 \cdot 036$ & $0 \cdot 074$ \\
\hline September 2002 & $6 \cdot 0$ & $7 \cdot 0$ & $6 \cdot 4$ & $5 \cdot 6$ & $0 \cdot 45$ & $0 \cdot 165$ & $0 \cdot 079$ & $0 \cdot 118$ \\
\hline May 2003 & $8 \cdot 9$ & $7 \cdot 1$ & $8 \cdot 6$ & $9 \cdot 2$ & $0 \cdot 98$ & $0 \cdot 238$ & $0 \cdot 105$ & 0.555 \\
\hline July 2003 & $5 \cdot 7$ & $6 \cdot 3$ & $6 \cdot 1$ & $6 \cdot 1$ & 0.57 & $0 \cdot 770$ & 0.332 & 0.902 \\
\hline September 2003 & $5 \cdot 9$ & $6 \cdot 6$ & $5 \cdot 6$ & $5 \cdot 3$ & $0 \cdot 68$ & $0 \cdot 144$ & $0 \cdot 328$ & $0 \cdot 660$ \\
\hline
\end{tabular}

(d) diploid; (t) tetraploid; (th) tetraploid hybrid.

Table 6 Leaf mass and the number of tillers per square metre when heifers entered the paddocks at the start of 24-h behaviour recordings in 2002 and 2003.

\begin{tabular}{|c|c|c|c|c|c|c|c|c|}
\hline & \multicolumn{4}{|c|}{ Variety } & \multirow[b]{2}{*}{ s.e.d } & \multicolumn{3}{|c|}{ Level of significance } \\
\hline & Belramo (d) & Glen (d) & Rosalin (t) & AberExcel (th) & & Ploidy & $\begin{array}{l}\text { Belramo vs. } \\
\text { Glen }\end{array}$ & $\begin{array}{l}\text { Rosalin vs. } \\
\text { AberExcel }\end{array}$ \\
\hline \multicolumn{9}{|c|}{ Leaf mass (kg DM ha $\left.{ }^{-1}\right)$} \\
\hline July 2002 & 1398 & 1809 & 1545 & 1665 & $209 \cdot 3$ & $0 \cdot 990$ & 0.097 & 0.586 \\
\hline September 2002 & 1231 & 1317 & 1265 & 1030 & $160 \cdot 8$ & $0 \cdot 308$ & $0 \cdot 610$ & $0 \cdot 194$ \\
\hline May 2003 & 1875 & 2360 & 2027 & 1847 & $425 \cdot 5$ & $0 \cdot 570$ & $0 \cdot 298$ & 0.688 \\
\hline July 2003 & 1025 & 1479 & 1413 & 1037 & $260 \cdot 3$ & $0 \cdot 889$ & $0 \cdot 131$ & $0 \cdot 198$ \\
\hline September 2003 & 902 & 1345 & 1120 & 769 & $176 \cdot 1$ & $0 \cdot 200$ & $0 \cdot 046$ & 0.093 \\
\hline \multicolumn{9}{|c|}{ Number of tillers $\left(1000 \mathrm{~m}^{-2}\right)$} \\
\hline July 2002 & $13 \cdot 1$ & $10 \cdot 7$ & $9 \cdot 5$ & $5 \cdot 4$ & $1 \cdot 38$ & $0 \cdot 004$ & $0 \cdot 140$ & 0.025 \\
\hline September 2002 & $8 \cdot 2$ & $9 \cdot 8$ & $8 \cdot 7$ & $5 \cdot 6$ & 1.57 & $0 \cdot 141$ & $0 \cdot 343$ & 0.090 \\
\hline May 2003 & $8 \cdot 7$ & $12 \cdot 3$ & $6 \cdot 8$ & $5 \cdot 4$ & $1 \cdot 15$ & 0.002 & 0.019 & $0 \cdot 247$ \\
\hline July 2003 & $10 \cdot 6$ & $13 \cdot 2$ & $8 \cdot 4$ & $8 \cdot 2$ & $1 \cdot 15$ & $0 \cdot 004$ & 0.069 & $0 \cdot 848$ \\
\hline September 2003 & $9 \cdot 4$ & 8.9 & $8 \cdot 4$ & $6 \cdot 1$ & $2 \cdot 01$ & $0 \cdot 227$ & $0 \cdot 799$ & $0 \cdot 307$ \\
\hline
\end{tabular}

(d) diploid; (t) tetraploid; (th) tetraploid hybrid.

strongly confounded with sward $\times$ management interactions.

There are fundamental physiological differences in the way cattle graze compared with sheep. Cattle, generally, use a prehensile tongue to 'sweep' forage into the mouth, whilst sheep rely on a split upper lip and tend to nibble swards. However, sheep can also deal effectively with tall swards (Penning et al., 1994) by inserting their mouth sideways into swards and severing, at a single bite, bunches of long leaves and pseudostems which are gradually drawn into the mouth. While grazing, cattle have a lower total jaw movement rate (e.g. Orr et al., 2004b) than sheep (e.g. Penning et al., 1991), and sheep also have higher proportions of the grazing jaw movements (between one-half and two-thirds) as chews depending on sward height (Penning et al., 1994). Yearling dairy heifers rotationally stocked on perennial ryegrass swards (Orr et al., 2004b) had generally similar total jaw movement rates during the first hour on a new paddock to those in the present experiment. Values were 
Table 7 Sheath tube and leaf lengths when heifers entered the paddocks at the start of $24 \mathrm{~h}$ behaviour recordings in 2002 and 2003.

\begin{tabular}{|c|c|c|c|c|c|c|c|c|}
\hline & \multicolumn{4}{|c|}{ Variety } & \multirow[b]{2}{*}{ s.e.d } & \multicolumn{3}{|c|}{ Level of significance } \\
\hline & Belramo (d) & Glen (d) & Rosalin (t) & AberExcel (th) & & Ploidy & $\begin{array}{l}\text { Belramo vs. } \\
\text { Glen }\end{array}$ & $\begin{array}{l}\text { Rosalin vs. } \\
\text { AberExcel }\end{array}$ \\
\hline \multicolumn{9}{|c|}{ Sheath tube length (mm) } \\
\hline \multicolumn{9}{|l|}{ Oldest } \\
\hline July 2002 & 30 & 44 & 32 & 57 & $6 \cdot 3$ & $0 \cdot 144$ & 0.063 & $0 \cdot 008$ \\
\hline September 2002 & 38 & 42 & 35 & 31 & $5 \cdot 2$ & $0 \cdot 106$ & $0 \cdot 562$ & $0 \cdot 403$ \\
\hline May 2003 & 60 & 44 & 64 & 87 & $18 \cdot 3$ & $0 \cdot 116$ & $0 \cdot 426$ & $0 \cdot 260$ \\
\hline July 2003 & 24 & 31 & 40 & 32 & $4 \cdot 6$ & $0 \cdot 041$ & $0 \cdot 143$ & $0 \cdot 127$ \\
\hline September 2003 & 29 & 43 & 32 & 28 & $6 \cdot 9$ & $0 \cdot 267$ & $0 \cdot 102$ & $0 \cdot 564$ \\
\hline \multicolumn{9}{|l|}{ Second oldest } \\
\hline July 2002 & 44 & 58 & 45 & 106 & $15 \cdot 2$ & 0.065 & $0 \cdot 393$ & 0.007 \\
\hline September 2002 & 50 & 55 & 46 & 47 & $8 \cdot 1$ & 0.334 & $0 \cdot 577$ & $0 \cdot 971$ \\
\hline May 2003 & 110 & 74 & 120 & 160 & $35 \cdot 5$ & $0 \cdot 106$ & $0 \cdot 343$ & $0 \cdot 304$ \\
\hline July 2003 & 35 & 45 & 54 & 48 & $5 \cdot 4$ & 0.026 & $0 \cdot 121$ & $0 \cdot 286$ \\
\hline September 2003 & 36 & 52 & 40 & 38 & $8 \cdot 4$ & $0 \cdot 407$ & $0 \cdot 106$ & 0.887 \\
\hline \multicolumn{9}{|l|}{ Leaf length (mm) } \\
\hline \multicolumn{9}{|l|}{ Oldest FE } \\
\hline July 2002 & 81 & 115 & 100 & 143 & $11 \cdot 5$ & 0.026 & $0 \cdot 023$ & $0 \cdot 009$ \\
\hline September 2002 & 100 & 99 & 93 & 87 & $20 \cdot 3$ & 0.516 & 0.984 & $0 \cdot 772$ \\
\hline May 2003 & 105 & 96 & 122 & 150 & $32 \cdot 0$ & $0 \cdot 165$ & $0 \cdot 802$ & $0 \cdot 414$ \\
\hline July 2003 & 62 & 78 & 87 & 72 & $11 \cdot 4$ & $0 \cdot 280$ & $0 \cdot 209$ & $0 \cdot 236$ \\
\hline September 2003 & 63 & 94 & 75 & 69 & $9 \cdot 2$ & $0 \cdot 345$ & 0.015 & 0.552 \\
\hline \multicolumn{9}{|l|}{ Second oldest FE } \\
\hline July 2002 & 109 & 160 & 145 & 205 & $10 \cdot 5$ & 0.002 & 0.003 & $0 \cdot 001$ \\
\hline September 2002 & 126 & 127 & 127 & 142 & $17 \cdot 3$ & 0.536 & $0 \cdot 960$ & $0 \cdot 416$ \\
\hline May 2003 & 117 & 123 & 151 & 174 & $35 \cdot 8$ & $0 \cdot 148$ & $0 \cdot 881$ & 0.547 \\
\hline July 2003 & 86 & 105 & 130 & 107 & $19 \cdot 1$ & $0 \cdot 139$ & $0 \cdot 378$ & $0 \cdot 269$ \\
\hline September 2003 & 84 & 98 & 100 & 103 & $13 \cdot 9$ & $0 \cdot 298$ & 0.359 & 0.859 \\
\hline \multicolumn{9}{|l|}{ Expanding } \\
\hline July 2002 & 72 & 95 & 93 & 132 & $7 \cdot 6$ & 0.002 & 0.024 & 0.002 \\
\hline September 2002 & 82 & 81 & 80 & 88 & $9 \cdot 7$ & 0.737 & 0.905 & 0.435 \\
\hline May 2003 & 68 & 70 & 93 & 92 & $15 \cdot 3$ & 0.073 & 0.881 & $0 \cdot 964$ \\
\hline July 2003 & 65 & 73 & 84 & 72 & $10 \cdot 5$ & $0 \cdot 275$ & $0 \cdot 459$ & 0.333 \\
\hline September 2003 & 52 & 71 & 61 & 54 & $8 \cdot 6$ & 0.523 & 0.071 & $0 \cdot 469$ \\
\hline
\end{tabular}

(d) diploid; (t) tetraploid; (th) tetraploid hybrid.

FE, fully expanded.

approximately 93 jaw movements $\min ^{-1}(76-78$ bites plus 15-17 chews min $^{-1}$ ) compared with 87 jaw movements $\min ^{-1}$ ( 67 bites plus 20 chews $\min ^{-1}$ ) measured in the present experiment. The biting and total jaw movement rates measured by Orr et al. (2004b), when the dairy heifers entered the new paddock, may have been marginally higher because the grazing periods in that experiment were of 2-3 weeks duration, so the heifers may have been hungrier (Greenwood and Demment, 1988) prior to their next move than in the present study where they moved to a new paddock each day.

\section{Eating time, ruminating time and rumination chewing}

Daily intake may be thought of as the product of IR and eating time but, while both of these factors were measured, daily intake was not calculated here because IR was only measured during the first hour of the $24 \mathrm{~h}$ that the heifers spent on the paddock. It is very likely that IR declined (McGilloway et al., 1999; Barrett et al., 2001; Orr et al., 200 lb) during the grazing period as the swards were grazed down. However, while we cannot be certain that there were no differences between 
varieties in IR over the whole 24-h grazing period, there were no significant differences in eating time (mean $521 \mathrm{~min} 24 \mathrm{~h}^{-1}$ ), or ruminating time (mean $462 \mathrm{~min}$ $24 \mathrm{~h}^{-1}$ ) - apart from significantly higher ruminating time in July 2002 for heifers grazing diploid compared with tetraploid varieties - or the number of rumination chews (mean $78 \mathrm{~min}^{-1}$ or 63 bolus $^{-1}$ ). Furthermore, it is likely that daily intakes were also similar for the four varieties because liveweight gains, which provide a very robust measure of variety performance, were not significantly different (Table 4) between the heifers grazing the four varieties. McCallum and Thomson (1994) also found that ryegrass cultivar had little effect on dairy animal performance when four cultivars were rotationally grazed with dairy calf replacements or cows in a series of tests. In contrast, Hazard et al. (1998) found a significant cultivar effect on intake by sheep when two intermediate-heading and two late-heading diploid perennial ryegrass varieties were rotationally grazed. These same four cultivars were rotationally grazed by cows in the following year (Emile et al., 2000) and there were significant effects of cultivar on milk yield which were attributed to sward structure traits such as lamina length, sheath weight and green lamina ratio. These authors identified the need for further investigation of morphological traits which could be used as selection criteria to increase cultivar performance under grazing.

\section{Effects of sward chemical and morphological factors on IR}

Differences between grass varieties in IR by sheep have been related in part to sward factors in previous studies (Orr et al., 2003, 2004a). Here, sward chemical and morphological factors (Smith et al., 2001; Gilliland et al., 2002) were also examined to see whether these might provide an explanation of the intake characteristics measured.

In the previous studies (Orr et al., 2003, 2004a) with continuously stocked sheep there was some evidence that, in 1998 but not 1999, IR was positively correlated with nitrogen concentration and digestibility of grass snips (comprising predominantly of live leaves) designed to be representative of the material ingested by the sheep. In those studies, the tetraploid hybrid varieties had high intake characteristics and high nitrogen concentrations in the leaves (Orr et al., 200la). In the fifteen intermediate-heading varieties examined, WSC concentration was not found to be related to IR under continuous stocking conditions where the diet comprised mainly leaves, rather than sheath and pseudostem which contain higher concentrations of WSC (McGrath, 1988). In the present experiment, there were small effects of ploidy on herbage quality and for the diploid and tetraploid varieties overall mean values were 711 vs. $714 \mathrm{~g} \mathrm{DOM} \mathrm{kg}^{-1}$ DM for digestibility, $32 \mathrm{vs.}$ $33 \mathrm{~g} \mathrm{~N} \mathrm{~kg}^{-1} \mathrm{DM}$ for nitrogen concentration and 181 vs. $179 \mathrm{~g} \mathrm{WSC} \mathrm{kg}^{-1}$ DM for WSC concentration.

Herbage quality is widely assumed to be related to grazing intake, animal performance and protein utilization and increased digestibility has received much attention as a breeding trait (Wilkins, 1997) along with the concentrations of N, WSC and fibre (Wilkins and Humphreys, 2003). Hence, perennial ryegrass breeding programmes have focussed on these quality traits (Beerepoot and Agnew, 1997), along with plant persistence, tolerance to environmental stresses and resistance to pathogens and invertebrate pests. Armstrong et al. (1986) harvested herbage from five indigenous hill plant communities and from sown perennial ryegrass and white clover swards, ranging from 371 to $796 \mathrm{~g} \mathrm{DOM} \mathrm{kg}^{-1}$ OM (organic matter digestibility, OMD), which was offered to housed sheep in pens. These authors concluded that digestibility accounted for much of the variation and provided a good general index of potential intake. The range in digestibility (DOMD) values for the fifteen intermediate-heading perennial ryegrass varieties grazed by sheep in the experiment of Orr et al. (2001a, 2003) was much more limited (621-736 $\left.\mathrm{g} \mathrm{DOM} \mathrm{kg}^{-1} \mathrm{DM}\right)$ than the range reported by Armstrong et al. (1986). The same was true in the present experiment where the range in DOMD values was 663-763 $\mathrm{g} \mathrm{DOM} \mathrm{kg}^{-1} \mathrm{DM}$ and there was no correlation between DM IR (measured in the first hour on the new paddock) and the plant and animal factors shown in Tables 1-3 and 5-7 for the three periods in which IR was measured (September 2002, July and August 2003), apart from a positive correlation $(P<0.001)$ with DM content of the herbage (range 199-258 $\mathrm{g} \mathrm{kg}^{-1}$ ) in September 2002. Taweel (2004) investigated rumen capacity in dairy cows and screened six perennial ryegrass varieties for their ruminal clearance and degradation rates and concluded there was only a narrow range for selection for these factors. Moreover, feeding high-sugar grass in a comparison with four other varieties did not lead to increased DM intake or milk yield under stall-feeding or daily stripgrazing conditions.

The measurements of sheath tube and leaf lengths provided 'snap-shots' of the plant dimensions at a point in time but are difficult to interpret without information on appearance date of leaves. Sward structure of a variety is likely to change with season and this could result in differences in IR. There were significant differences in some of these attributes and in tiller population density between and within ploidies, which might have been expected to have some influence on intake characteristics, but this was not generally found 
under rotation grazing with cattle. Hazard and Ghesquiere (1997) found a genotype $\times$ management interaction with short-leaved genotypes giving a better yield under frequent cutting than long-leaved genotypes, but the relationship was inverted under infrequent cutting.

\section{Conclusions}

It is evident from these and previous results, obtained using the same four intermediate-heading varieties, that perennial ryegrass displays considerable plasticity under different managements. In the experiment reported here (with the exception of a within-diploid comparison in one of three measurement periods), IR were not significantly different between the varieties, nor were eating times. In order to understand further these interactions there is a need to identify more closely the mechanisms involved. As part of this process, grass variety evaluations using continuously stocked cattle swards are required in order to separate the effects of defoliation interval from those of grazing style of the different animal species. Then it will be possible to develop new varieties for grazing use which are matched with appropriate grazing-management recommendations.

\section{Acknowledgments}

This work was funded by the Department for Environment, Food and Rural Affairs of England and Wales and was carried out in accordance with the welfare standards approved by IGER's Ethical Review Procedure. IGER is supported by the Biotechnology and Biological Sciences Research Council.

\section{References}

Armstrong R.H., Common T.G. and Smith H.K. (1986) The voluntary intake and in vivo digestibility of herbage harvested from indigenous hill plant communities. Grass and Forage Science, 41, 53-60.

Barrett P.D., Laidaw A.S., Mayne C.S. and Christie H. (2001) Pattern of herbage intake rate and bite dimensions of rotationally grazed dairy cows as sward height declines. Grass and Forage Science, 56, 362-373.

BARRetT P.D., McGilloway D.A., LAidaw A.S. and MAyne C.S. (2003) The effect of sward structure as influenced by ryegrass genotype on bite dimensions and short-term intake rate by dairy cows. Grass and Forage Science, 58, 211 .

Beerepoot L.J. and Agnew R.E. (1997) Breeding for improved herbage quality in perennial ryegrass. In: Weddell J.R. (ed.) Seeds of Progress. British Grassland Society Occasional Symposium, No. 31, pp. 135-145. Reading: British Grassland Society.
CASEY I.A. (2000) A study of sward structure development and its influence on bite dimensions of grazing dairy cows. Ph.D. thesis, The Queen's University.

Emile J.-C., Hazard L., Betin M. and Monnerie C. (2000) Cultivar effect in perennial ryegrass on milk production of dairy cows. In: Soegaard K., Ohlsson C., Schested J., Hutchings N.J. and Kristensen T. (eds), Grassland Farming: Balancing Environmental and Economic Demands, Proceedings of the 18th General meeting of the European Grassland Federation, pp. 235-237. Aalborg, Denmark.

Frame J. (1981) Herbage mass. In: Hodgson J., Baker R.D., Davies A., Laidlaw A.S. and Leaver J.D. (eds), Sward Measurement Handbook, pp. 39-69. Hurley: The British Grassland Society.

GENSTAT (1987) Genstat 5 Committee Reference Manual. Oxford: Clarendon Press.

GibB M.J. (1998) Animal grazing/intake terminology and definitions. In: Keane M.G. and O'Riordan E.G. (eds), Pasture Ecology and Animal Intake, Occasional Publication No. 3, Proceedings of a Workshop held in Dublin, September 1996, for Concerted Action, AIR-CT93-0947, pp. 21-37. Dunsany, Ireland: Teagasc.

Gilliland T.J., Barrett P.D., Mann R.L., Agnew R.E. and FeAron A.M. (2002) Canopy morphology and nutritional quality traits as potential grazing value indicators for Lolium perenne varieties. Journal of Agricultural Science, Cambridge, 139, 257-273.

Gowen N., O’Donovan M., Casey I., Rath M., Delaby L. and Stakelum G. (2003) The effect of grass cultivars differing in heading date and ploidy on the performance and dry matter intake of spring calving dairy cows at pasture. Animal Research, 52, 321-336.

Greenwood G.B. and Demment M.W. (1988) The effect of fasting on short-term cattle grazing behaviour. Grass and Forage Science, 43, 377-386.

Hazard L. and Ghesquiere M. (1997) Productivity under contrasting cutting regimes of perennial ryegrass selected for short and long leaves. Euphytica, 95, 295-299.

Hazard L., de Moraes A., Betin M., Traineau R. and Emile J.-C. (1998) Perennial ryegrass cultivar effects on intake of grazing sheep and feeding value. Annales de Zootechnie, 47, 117-125.

Huckle C.A., Nuthall R. and Gibb M.J. (1994) The use of short-term weight changes to measure intake rates in grazing dairy cattle. Fourth Research Meeting of the British Grassland Society, September 1994, Reading, UK. pp. 157158.

Jones D.I.H. and Haywood M.V. (1975) The effect of pepsin treatment of herbage on the prediction of dry matter digestibility from solubility in fungal cellulase solutions. Journal of the Science of Food and Agriculture, 26, $711-718$.

McCallum D.A. and Thomson N.A. (1994) The effect of different perennial ryegrass cultivars on dairy animal performance. Proceedings of the New Zealand Society of Animal Production, 54, 87-90.

McGilloway D.A., Cushnahan A., Laidaw A.S., Mayne C.S. and KilPatrick D.J. (1999) The relationship between level of sward height reduction in a rotationally grazed 
sward and short-term intake rates of dairy cows. Grass and Forage Science, 54, 116-126.

McGrath D. (1988) Seasonal variation in the water-soluble carbohydrates of perennial and Italian ryegrass under cutting conditions. Irish Journal of Agricultural Research 27, 131-139.

Nevens F. and Reheul D. (2003) Permanent grassland and 3 -year leys alternating with 3 years of arable land: 31 years of comparison. European Journal of Agronomy, 19, 77-90.

OrR R.J., Martyn T.M. and Clements R.O. (2001a) Evaluation of perennial ryegrass varieties under frequent cutting or continuous stocking with sheep. Plant Varieties and Seeds, 14, 181-199.

OrR R.J., Rutter S.M., Penning P.D. and Rook A.J. (200lb) Matching grass supply to grazing patterns for dairy cows. Grass and Forage Science, 56, 352-361.

OrR R.J., CoOK J.E., Champion R.A., Penning P.D. and Rook A.J. (2003) Intake characteristics of perennial ryegrass varieties when grazed by sheep under continuous stocking management. Euphytica, 134, 247-260.

ORR R.J., COOK J.E., CHAMPION R.A. and RoOK A.J. (2004a) Relationships between morphological and chemical characteristics of perennial ryegrass varieties and intake by sheep under continuous stocking management. Grass and Forage Science, 59, 389-398.

ORR R.J., RUtTER S.M., YARRow N.H., CHAMpion R.A. and Rook A.J. (2004b) Changes in ingestive behaviour of yearling dairy heifers due to changes in sward state during grazing down of rotationally-stocked ryegrass or white clover pastures. Applied Animal Behaviour Science, 87, 205-222.

Penning P.D. and Hooper G.E. (1985) An evaluation of the use of short-term weight changes in grazing sheep for estimating herbage intake. Grass and Forage Science, 40, 79-84.

Penning P.D., Parsons A.J., OrR R.J. and Treacher T.T. (1991) Intake and behaviour responses by sheep to changes in sward characteristics under continuous stocking. Grass and Forage Science, 46, 15-28.

Penning P.D., Parsons A.J., OrR R.J. and Hooper G.E. (1994) Intake and behaviour responses by sheep to changes in sward characteristics under rotational grazing. Grass and Forage Science, 49, 476-486.
Rook A. J. and Penning P. D. (1991) Synchronisation of eating, ruminating and idling activity by grazing sheep. Applied Animal Behaviour Science, 32, 157-166.

RUTTER S.M. (2000) Graze: a program to analyze recordings of the jaw movements of ruminants. Behaviour Research Methods, Instruments and Computers, 32, 86-92.

Rutter S.M., Champion R.A. and Penning P.D. (1997) An automatic system to record foraging behaviour in freeranging ruminants. Applied Animal Behaviour Science, 54, 185-195.

Smith K.F., Simpson R.J., Culvenor R.A., Humphreys M.O., Prud'homme M.P. and ORAM R.N. (2001) The effects of ploidy and a phenotype conferring a high water-soluble carbohydrate concentration on carbohydrate accumulation, nutritive value and morphology of perennial ryegrass (Lolium perenne L.). Journal of Agricultural Science, Cambridge, 136, 65-74.

Swift G., Vipond J.E., McClelland T.H., Cleland A.T., Milne J.A. and HunTER E.A. (1993) A comparison of diploid and tetraploid perennial ryegrass and tetraploid ryegrass/ white clover swards under continuous sheep stocking at controlled sward heights. 1. Sward characteristics. Grass and Forage Science, 48, 279-289.

TAWEeL H.Z. (2004) Perennial ryegrass for dairy cows: grazing behaviour, intake, rumen function and performance. Ph.D. thesis, Wageningen University.

Tecator (1987) Tecator Application Note 02.18, AN 86/87. Determination of Kjeldahl Nitrogen Content and Kjeldahl System 1030. Thornbury, Bristol: Tecator Ltd.

Thomas T.A. (1977) An automated procedure for the determination of soluble carbohydrates in herbage. Journal of the Science of Food $\theta$ Agriculture, 28, 639-642.

Thomson N.A., McCallum D.A., Howse S., Holmes C.W., MatheWs P.N.P. and MatheW C. (1997) Estimation of dairy pastures - the need for standardisation. Proceedings of the New Zealand Society of Animal Production, 59, $221-$ 225.

WILKINS P.W. (1997) Useful variation in in vitro digestibility within perennial ryegrass. Euphytica, 93, 249-255.

Wilkins P.W. and Humphreys M.O. (2003) Progress in breeding perennial forage grasses for temperate agriculture. Journal of Agricultural Science, Cambridge, 140, 129-150. 